\title{
Environmental Education On The Basis of Ecotourism
}

\author{
Desy Safitri \\ State University of Jakarta \\ Jakarta, Indonesia \\ desysafitri04@yahoo.com
}

\begin{abstract}
The purpose of this research is to develop environmental education model on the basis of ecotourism. Specific target in this research is: (1) to develop valid environmental education model draft on the basis of ecotourism; (2) to develop practical and effective environmental education model on the basis of ecotourism; and (3) to disseminate and implement environmental education model on the basis of ecotourism. The method of research used research and development. The result of this research is useful as a guidance to manage tourism location sustainably and environmental friendly. Through environmental education based on ecotourism, the tourism activities can be carried out without deteriorating environment.
\end{abstract}

Keywords-environmental education, environmental education model, tourism location

ecotourism,

\section{INTRODUCTION}

Indonesia as an island country has potency in variety of tourism location. This is related to uniqeness, natural resources, culture, and human resources as tourism capital and necessary to be managed sustainably so that it will be development capital and social welfare. Tourism activities frequently causes environmental damage giving negative impacts to environmental sustainability in tourism location. In developing society for environmental awareness movement to carry out environmental activities leading to sustainable and responsible tourism, this research is designed to develop environmental education model on the basis of ecotourism.

Tourism development was greatly related to environmental quality of location sensitive to environmental deterioration. Higher tourism activities are correlated with environmental deterioration such as environmental pollution, scenery damage, vandalism, or unfriendly attitude of the society.

Developing ecotourism in Karimunjawa aimed to protect Indonesia's biodiversity [1]. This concept is an alternative ways to use biodiversity sustainably. Ecotourism can promote environmental conservation in Karimunjawa. However, this study did not investigate the appropriate model used for environmental education based on ecotourism.

Implementation of ecotourism in Nepal was not promising because of low commitment of governmental policy and planning strategy [2]. Study result showed that policy must be integrative, collaborative and comprehensive in order to achieve successful ecotourism. However, this study only investigated the challenges and opportunities of ecotourism in Nepal.
There were some economic and non economic benefits for local community members by participating in ecotourism programmes [3]. Intervention of communities in ecotourism diminished excessive dependence on forest resources for their livelihood. However, this study did not examine the model to educate the local communities based on ecotourism.

The interaction between tourists and residents influenced tourism on the local population [4]. The complex societal relationship with tourism led to the success of tourism industry. Nevertheless, this study did not discuss about educating residents with the appropriate model of ecotourism.

This research is to develop environmental education model on the basis of ecotourism leading to carry out tourism activities without deteriorating environment.

\section{METHOD}

The study of Chen, Y.; Siahaan, G.; \& Tangkau, P (2014) found that ecotourism was not fully implemented. Most of the tourism type was mass tourism leadign to a strain on Karimunjawa's resources [1]. Local government had low capacity to do basic services such as providing training and socializing ecotourism policies. Lack of awareness about ecoturism lead to inefficiencies in implementing ecotourism policy at the local level. However, this study did not give appropriate model of ecotourism promoted to use biodiversity sustainably.

There were no clear guidelines of ecotourism. Concrete strategies were needed for ecotourism development in developing countries [2]. Capacity building of local communities was needed to develop ecotourism. Problems related to ecotourism implementation were sustainable energy systems, proper waste management, human and animal rights respect, women's empowerment, sustainable consumption system, political instability, and controlling social problems. The objectives of ecotourism in Nepal were sustainable resource management, maximum participation of local people, promoting alternative energy, poverty alleviation, environmental awareness, community development, heritage conservation, and self-sustaining tourism. However, this study only focused on challenges and opportunities about ecotourism in Nepal.

Local community made strong foundation to ensure dimansions of sustainability with ecotourism for an enhanced well being [3]. Ecotourism programmes aimed to ensure maximum participation of local tribal communities in 
ecotourism, provide alternative source of livelihood of tribal families, study capacity of sanctuary of tourism, utilize existing tourist facilities to meet future demands, provide enjoyable experience for visitors, and spread wildlife conservation to the masses. However, this research did not investigate the model to educate the local communities on the basis ecotourism.

Potential benefits of ecotourism development were environmental education and consciousness raising, stimulation of preservation of nature, economic diversification, empowerment of deprived groups, encouragement of community organization, and promotion of local culture [4]. Ecotourism development improved natural areas protection. Ecotourism growth in Costa Rica and its social, economic, and environmental effects was described that the importance of Costa Rica as a model for ecotourism. However, this study did not explain in detail about the model of ecotourism in environmental education.

Tomomi, I. investigated that ecotourism was promoted in Bali in Indonesia to help preserve biodiversity in Indonesia. Strengthening Indonesian ecotourism aimed to improve awareness of the natural conservation needs, develop environmental education quality, and provide economic benefits to local people involved in ecotourism activities. In Bali, ecotourism to prohibit the province from the negative impacts of tourism on local society. However, this study did not explain in detail about the moel of ecotourism in environmental education.

\section{RESULTS AND DICUSSION}

This research and development conducted in Jabodetabek (Jakartaconsisted of ten steps: (1) potency and problem; (2) data collection and analysis; (3) model design; (4) model validation; (5) model revision; (6) model trial test; (7) model revision; (8) model usage trial test; (9) model revision; (10) model production.

This research discussed about model draft of environmental education on the basis of ecotourism. Educational application focusing on environmental conservation and preserve lives and local community welfare was not optimally done leading to diminish environmental quality. This research involved multidiscipline approach and integration with empirical science. This research mapped various problems faced by diminishing of ecotourism values related to tourism. The importance of this research done to preserve environment can be a guidance in environmental education so that tourism locations can be developed comprehensively in order to have society with environmental awareness for sustainable tourism and environmental friendly.

Ecotourism including minimizing environmental impacts, respecting local culture, and maximazing benefits for local communities, and maximazing tourist satisfaction. Variety of values contained in ecotourism was given by environmental education consisting of cultural aspect values, environmental conservation, local communities lives and welfares, and learning.
Educational aspects were main parts in managing tourism due to bringing social mission to realize humans' existences, environment, and impacts if there was mistakes in managing global environment usage. In describing this mission, there was conflicted with economical measurement or trapped in strict educational method. One of ecotourism objectives was that it had to describe environmental wisdom and asked people to appreciate everything. Through simplicity, it was used as local society guidance to preserve natural conservation. Ecotourists got knowledge through integration with environment and society. Society was educated by transferring knowledge from ecotourists as realization of principle to give benefits to local communities and mutual relationship between ecotourists and visitors. Interaction between visitors and tourism objects made ecotourism activities delivering messages of environmental education leading to changing attitude positively. Sustainable ecotourism was supported by interrelated aspects consisting of economy, social, and environmental aspects.

Sustainable tourism ecologically focusing primarily to the experiences at natural location was to improve understanding, appreciation, and conservation to environment and culture. This study described that ecotourism was tourism activities responsible for local communities welfare and environmental conservation so that values in environmental education were needed to be internalized. Environmental education was advocate real step to solve environmental crisis through managing and using natural resources sustainably and regularly by protecting ecological process and biodiversity conservation. In addition to this, environmental education was related with sustainable development in Indonesia so that society had awareness of natural resources conservation and its problems having knowledge, attitude, expertise, motivation, and commitment to seek solution alternatives specifically for tourism location. Ecotourism involved educational components and interpretation of natural aspects and local culture. Visitors had to learn aobut something and develop understanding about local characteristics and natural process.

\section{CONCLUSION}

Ecotourism is tourism activities supporting natural resources conservation and not focused on profit oriented. Ecotourism places high priority on ecotourists, local communities, environment, and management. Environmental education on the basis of ecotourism provides understanding, awareness, attitude, and behavior appropriately suitable with norms or environmental ethics so that sustainable tourism location will be maintained leading to keep up environmental conservation, improve society welfare, guarrantee visitor satisfaction, and improve integration and unity of developing local communities and development zone. Tourism location management integrated with environmental education is done in order that natural resources usage activities and environmental sources services are done comprehensively leading to achieve optimal and sustainable development result. Ecotourism should be implemented in all tourism location in Indonesia so that sustainable resourse management, maximum 
participation of local people, promoting alternative energy, poverty alleviation, environmental awareness, community development, heritage conservation, and self-sustaining tourism can be ahieved optimally.

\section{REFERENCES}

[1] Chen, Y.; Siahaan, G.; \& Tangkau, P. "The management and implementation of ecotourism in Indonesia: a case study of Karimunjawa Islands”. SEBAR for USAID and Bappenas, 2014.
[2] Yogi, H. N. "Eco-tourism and sustainability-opportunitis and challenges in the case of Nepal". Master Thesis, Department of Sustainable Development, University of Uppsala, 2010

[3] Vinodan, A \& Manalel, J. "Local eonomic benefits of ecotourism: a case study on Parambikulam Tiger Riserve in kerala, India. Sajth, 4(2), 2011.

[4] Stone, C. W. "Ecotourism in the Galapos Islands: a case study in the anthropology of Tourism". Anthropology Department Honors Papers, 2014, Paper 8

[5] Tomomi, I. "Ecotourism in Bali: backgrounds, present conditions and challenges". Doctoral program in international relations, graduate school of international relations, Ritsumelkan Universit 